\title{
Keefektifan Model Pembelajaran Problem Based Learning Terhadap Motivasi dan Hasil Belajar
}

\author{
Erni Sriwahyuni \\ Program Studi Teknologi Pendidikan \\ Universitas PGRI Adi Buana Surabaya, Indonesia \\ Email: ernisriwahyuni69@gmail.com
}

Iskandar Wiryokusumo

Program Studi Teknologi Pendidikan Universitas PGRI Adi Buana Surabaya, Indonesia

Email: wiryokusumoiskandar@gmail.com

Hari Karyono

Program Studi Teknologi Pendidikan Universitas PGRI Adi Buana Surabaya, Indonesia

Email: harikaryana@yahoo.com

\begin{abstract}
Abstrak
Menghadapi diberlakukannya Asean Economic Community (AEC) pada Tahun 2015 lalu, nampak sangat dibutuhkan sumber daya manusia (SDM) yang handal, berdaya cipta, dan mampu berinovasi. SDM yang diharapkan merupakan produk atau hasil cipta dari proses pendidikan yang telah dilakukan. Tujuan penelitian ini adalah untuk menganalisis adanya pengaruh interaksi antara model pembelajaran problem based learning, motivasi, dan hasil belajar. Jenis Penelitian ini menggunakan pendekatan kuantitatif dengan desain eksperimen kuasi eksperimen. Metode pengumpulan data untuk variable independent menggunakan angket, sedangkan untuk variable hasil belajar mengunakan dokumen nilai tes atau ujian. Untuk menguji validitas dan reliabilitas instrumen dilakukan uji dengan rumus Cronbach Alpha. Sedangkan untuk uji hipotesis digunakan Uji statistik menggunakan Anava dua jalur dengan bantuan SPSS. Hasil Penelitian ini adalah terdapat pengaruh interaksi antara model pembelajaran PBL dan model direct learning dengan motivasi belajar siswa terhadap hasil belajar Fisika pada siswa Kelas XI IPA SMA Negeri 1 Dawarblandong dan SMA Negeri 2 Kota Mojokerto, hal ini ditunjukkan dari nilai $F_{\text {hitung }}=9,985$ dengan angka signifikansi sebesar 0,003 .
\end{abstract}

Kata Kunci: model PBL, model direct learning, motivasi belajar, hasil belajar.

\section{Pendahuluan}

Menghadapi diberlakukannya Asean Economic Community (AEC) pada Tahun 2015 lalu, nampak sangat dibutuhkan sumber daya manusia (SDM) yang handal, berdaya cipta, dan mampu berinovasi. SDM yang diharapkan merupakan produk atau hasil cipta dari proses pendidikan yang telah dilakukan.Strategi pembelajaran yang baik dan sesuai diharapkan dapat mencapai tujuan pembelajaran dengan baik pula.

Namun, kenyataannya pada saat ini yang terjadi menunjukkan bahwa dalam pembelajaran fisika masih banyak guru yang enggan menggunakan strategi pembelajaran yang menarik, yang sesuai tujuan pembelajaran, bahwa juga belum mampu menggugah motivasi belajar siswa. Kondisi motivasi belajar yang rendah akan menyebabkan hasil belajar yang didapatkan juga rendah. Pernyataan ini didukung oleh penelitian yang telah dilakukan oleh Harahap (2014) yang menyimpulkan bahwa terdapat hubungan yang signifikan antara motivasi dan aktivitas belajar siswa terhadap hasil belajar kognitif siswa.

Berdasarkan studi pendahuluan yang telah dilakukan diketahui bahwa proses pembelajaran mata pelajaran Fisika di SMA belum maksimal diarahkan pada proses aktif siswa mengkonstruksi sendiri pengetahuannya dan belum maksimal diintegrasikan dengan masalah sesuai dengan kehidupan sehari-hari siswa. Termasuk dalam hal ini pembelajaran di SMA Negeri 1 Dawarblandong dan SMA Negeri 2 Kota Mojokerto. Kondisi ini terjadi karena kesulitan siswa dalam memahami makna soal yang sebenarnya ketika bentuk soal diubah. Pencapaian pemahaman siswa tidak bisa terlepas dari keberadaan seorang guru. Kemampuan seorang guru disamping menjelaskan konsep dan prinsip, guru juga harus mampu mengajar dengan menciptakan kondisi yang baik agar keterlibatan siswa secara aktif dapat berlangsung selama pembelajaran. Pada hakekatnya guru secara tidak langsung dituntut harus dapat mengembangkan pola pembelajaran yang dalam melibatkan siswa dalam belajar. Guru dituntut dapat memilih model pembelajaran yang dapat memacu semangat setiap siswa untuk secara aktif ikut terlibat dalam pengalaman belajar yang dilakukannya (Rusman, 2014).

Strategi pembelajaran yang bisa dilakukan sangat beragam, tapi belum maksimal dan belum memanfaatkan sumber belajar secara beragam. Relevan dengan pendapat di atas, secara kajian teoritik model PBL digunakan untuk menumbuhkan dan mengembangkan berpikir tingkat tinggi dalam situasi-situasi berorientasi masalah, mencakup belajar bagaimana belajar (Nur, 2011). Sependapat yang disampaikan oleh Rusman (2014) menyatakan bahwa model PBL digunakan untuk mengoptimalkan tujuan, kebutuhan, motivasi yang mengarahkan suatu proses belajar yang merancang berbagai macam kognisi pemecahan masalah. Menurut 
Ngalimun (2017) untuk meningkatkan kualitas proses dan hasil belajar, beberapa ahli menyarankan pengunaan paradigma pembelajaran kontrukstivistik untuk kegiatan belajar mengajar di kelas. Belajar koperatif bertujuan untuk memperoleh dan menemukan stuktur pemikiran umum yang berhubungan dengan bagaimana sesuatu terbentuk, tidak hanya menekankan pada pengetahuan tentang sesuatu secara deklaratif (Ma'mur, 2016). Penggunaan PBL dapat meningkatkan pemahaman siswa tentang apa yang mereka pelajari sehingga diharapkan mereka dapat menerapkannya dalam kondisi nyata pada kehidupan sehari-hari (Ngalimun, 2017). Senada dengan pendapat tersebut, Aqib \& murtadlo (2016) menuliskan bahwa model PBL sangat baik bagi pembinaan sikap ilmiah kepada siswa, sehingga siswa belajar memecahkan suatu masalah menurut prosedur kerja metode ilmiah. Salah satu solusi penggunaan model pembelajaran yang memungkinkan dikembangkannya keterampilan berpikir siswa (penalaran, komunikasi, dan koneksi) dalam pemecahan masalah adalah pembelajaran berbasis masalah (Rusman, 2012).

Penelitian yang dilakukan oleh Renata \& Sihombing (2016) menyimpulkan bahwa terdapat pengaruh model pembelajaran berbasis masalah terhadap hasil belajar siswa pada materi pokok dinamis di kelas X SMA Negeri 15 Medan. Begitu juga penelitian yang dilakukan oleh Pitriah, Sutrio, \& Taufik (2018) menyimpulkan bahwa terdapat pengaruh model pembelajaran berbasis masalah berbantuan alat peraga tiga dimensi terhadap hasil belajar fisika peserta didik. Relevan dengan yang dilakukan oleh Ernawati (2017) yang menyimpulkan ada perbedaan yang signifikan hasil belajar IPA siswa kelas VII SMP Taman Dewasa Ibu Pawiyatan Yogyakarta antara mengunakan model pembelajaran berbasis masalah dengan model pembelajaran konvensional. Berdasarkan pemikiran dan beberapa penelitian di atas, maka tujuan penelitian ini adalah apakah terdapat pengaruh interaksi antara model pembelajaran PBL dan model direct learning dengan motivasi belajar siswa terhadap hasil belajar Fisika pada siswa Kelas XI IPA SMA Negeri 1 Dawarblandong dan SMA Negeri 2 Kota Mojokerto.

\section{Metode}

Jenis Penelitian ini menggunakan pendekatan kuantitatif dengan desain eksperimen kuasi eksperimen. Metode pengumpulan data untuk variable independent menggunakan angket, sedangkan untuk variable hasil belajar mengunakan dokumen nilai tes atau ujian. Untuk menguji validitas dan reliabilitas instrumen dilakukan uji dengan rumus Cronbach Alpha. Sedangkan untuk uji hipotesis digunakan Uji statistik menggunakan Anava dua jalur dengan bantuan SPSS. Desain penulisan analisis data menggunakan factorial 2 × 2 yang dapat dilihat pada Tabel 1.

Tabel 1. Desain Analisis Penelitian

\begin{tabular}{lcc}
\hline \multicolumn{1}{c}{ Varibel Independent } & \multicolumn{2}{c}{ Model Pembelajaran $(\mathbf{X})$} \\
Variabel moderator & $\left(\mathrm{X}_{1}\right)$ & $\begin{array}{c}\text { Model Direct } \\
\text { Learning }\left(\mathrm{X}_{2}\right)\end{array}$ \\
\hline Motivasi belajar tinggi $\left(\mathrm{A}_{1}\right)$ & $\left(\mathrm{A}_{1} \mathrm{X}_{1}\right)$ & $\left(\mathrm{A}_{1} \mathrm{X}_{2}\right)$ \\
Motivasi belajar rendah $\left(\mathrm{A}_{2}\right)$ & $\left(\mathrm{A}_{2} \mathrm{X}_{1}\right)$ & $\left(\mathrm{A}_{2} \mathrm{X}_{2}\right)$ \\
\hline
\end{tabular}

Keterangan:

$\begin{array}{lll}\mathrm{A}_{1} \mathrm{X}_{1} & : & \begin{array}{l}\text { Hasil belajar kelompok siswa motivasi tinggi dengan menggunakan } \\ \text { model pembelajaran PBL }\end{array} \\ \mathrm{A}_{1} \mathrm{X}_{2}: & \begin{array}{l}\text { Hasil belajar kelompok siswa motivasi tinggi dengan menggunakan } \\ \text { model direct learning }\end{array} \\ \mathrm{A}_{2} \mathrm{X}_{1}: & \begin{array}{l}\text { Hasil belajar kelompok siswa motivasi rendah dengan menggunakan } \\ \text { model pembelajaran PBL }\end{array} \\ \mathrm{A}_{2} \mathrm{X}_{2}: & \begin{array}{l}\text { Hasil belajar kelompok siswa motivasi rendah dengan menggunakan } \\ \text { model direct learning }\end{array}\end{array}$

\section{Hasil dan Pembahasan}

Data hasil angket motivasi belajar yang dilakukan oleh 70 siswa pada kelas eksperimen dan 70 siswa pada kelas kontrol diurutkan (dirangking) dari skor motivasi belajar tertinggi sampai skor motivasi belajar terendah. Deskripsi statistik data motivasi belajar siswa pada kelas eksperimen dan kontrol dapat dilihat pada Tabel 2. Berdasarkan Tabel 2 dapat dijelaskan bahwa motivasi belajar pada kelas eksperimen dengan jumlah responden 70 siswa memiliki skor minimum sebesar 124 skor maksimum sebesar 129 dan skor rata-rata sebesar 150,18 dan nilai standar deviasi sebesar 15,97. Motivasi belajar pada kelas kontrol dengan jumlah responden 70 siswa memiliki skor minimum sebesar 182, skor maksimum sebesar 176, skor rata-rata sebesar 150,28 dan nilai standar deviasi sebesar 10,76. 
Tabel 2. Deskripsi Statistik Motivasi belajar Siswa Kelas Eksperimen dan Kelas Kontrol

\begin{tabular}{lccccc}
\multicolumn{1}{c}{ Kelas } & N & Min & Maks & Rata-rata & SD \\
\hline Problem Based Learning & 70 & 124 & 129 & 150,18 & 15,97 \\
Direct Learning & 70 & 182 & 176 & 150,28 & 10,76 \\
\hline
\end{tabular}

Deskripsi statistik skor hasil belajar kognitif pada kelas eksperimen dan kelas kontrol selengkapnya dapat dilihat pada Tabel 3 .

Tabel 3. Deskripsi Statistik Nilai Hasil Belajar Kognitif pada Kelas Eksperimen dan Kelas Kontrol

\begin{tabular}{lccccc}
\multicolumn{1}{c}{ Kelas } & N & Minimum & Maksimum & Rata-rata & SD \\
\hline Problem Based Learning & 70 & 60 & 95 & 80 & 8,26 \\
Direct Learning & 70 & 41 & 87 & 74 & 8,78 \\
\hline
\end{tabular}

Deskripsi data hasil belajar kognitif pada kelas eksperimen dan kelas kontrol dirangkum pada Tabel 3 yang menunjukkan bahwa hasil belajar kognitif pada kelas eksperimen dengan jumlah responden 70 siswa memiliki nilai minimum sebesar 60 nilai maksimum sebesar 95, nilai rata-rata sebesar 80 dan nilai standar deviasi sebesar 8,26 . Hasil belajar kognitif pada kelas kontrol dengan jumlah responden 70 siswa memiliki nilai minimum sebesar 41, nilai maksimum sebesar 87, nilai rata-rata sebesar 74, dan nilai standar deviasi sebesar 8,78.

Tabel 4. Deskripsi Statistik Skor Pengamatan Penilaian Psikomotorik pada Kelas Eksperimen dan Kelas Kontrol

\begin{tabular}{lccccc}
\hline \multicolumn{1}{c}{ Kelas } & N & Minimum & Maksimum & Rata-rata & SD \\
\hline Problem Based Learning & 70 & 2 & 4 & 3,37 & 0,51 \\
Direct Learning & 70 & 2 & 4 & 3,04 & 0,56 \\
\hline
\end{tabular}

Deskripsi data hasil pengamatan penilaian psikomotorik pada kelas eksperimen dan kelas kontrol dirangkum pada Tabel 4 yang menunjukkan bahwa hasil pengamatan penilaian psikomotorik pada kelas eksperimen dengan jumlah responden 70 siswa memiliki nilai minimum sebesar 2 nilai maksimum sebesar 4, nilai rata-rata sebesar 3,37 dan nilai standar deviasi sebesar 0,51. Hasil pengamatan penilaian psikomotorik pada kelas kontrol dengan jumlah responden 70 siswa memiliki nilai minimum sebesar 2, nilai maksimum sebesar 4, nilai rata-rata sebesar 3,04, dan nilai standar deviasi sebesar 0,56. Deskripsi statistik skor hasil belajar kognitif pada kelas eksperimen dan kelas kontrol selengkapnya dapat dilihat pada Tabel 5.

Tabel 5. Deskripsi Statistik Hasil Pengamatan Penilaian Afektif pada Kelas Eksperimen dan Kelas Kontrol

\begin{tabular}{lccccc}
\multicolumn{1}{c}{ Kelas } & N & Minimum & Maksimum & Rata-rata & SD \\
\hline Problem Based Learning & 70 & 3.40 & 5 & 4,21 & 0,56 \\
Direct Learning & 70 & 2,83 & 5 & 4,05 & 0,40 \\
\hline
\end{tabular}

Tabel 5 yang menunjukkan bahwa hasil pengamatan penilaian afektif pada kelas eksperimen dengan jumlah responden 70 siswa memiliki nilai minimum sebesar 3,40 nilai maksimum sebesar 5, nilai rata-rata sebesar 4,21 dan nilai standar deviasi sebesar 0,56. Hasil pengamatan penilaian afektif pada kelas kontrol dengan jumlah responden 70 siswa memiliki nilai minimum sebesar 2,83, nilai maksimum sebesar 13,00, nilai rata-rata sebesar 7,52 , dan nilai standar deviasi sebesar 2,53.

\section{a. Uji Kesamaan Awal}

Berdasarkan hasil dari uji-t didapatkan nilai thitung dengan signifikansi 0,995 lebih besar dari 0,05 , artinya skor rata-rata motivasi belajar kelas eksperimen dan kontrol adalah sama. Pemilihan kelas eksperimen dan kontrol memiliki rata-rata motivasi belajar yang sama.

\section{b. Uji Normalitas}

Uji normalitas data ini dilakukan terhadap data hasil belajar kognitif, hasil pengamatan penilaian psikomotorik, dan hasil pengamatan penilaian afektif pada masing-masing perlakuan kelas, yaitu pada kelas eksperimen dan pada kelas kontrol. Ringkasan uji normalitas dapat dilihat pada Tabel 6 dan Tabel 7.

Tabel 6. Hasil Uji Normalitas Skor Hasil Belajar Kognitif Kelas Eksperimen dan Kontrol

\begin{tabular}{|c|c|c|c|c|}
\hline & \multirow[b]{2}{*}{ Kelas } & \multicolumn{3}{|c|}{ Kolmogorov-Smirnov ${ }^{a}$} \\
\hline & & Statistic & $D f$ & Sig. \\
\hline \multirow[t]{2}{*}{ Hasil belajar kognitif } & Eksperimen & 0.162 & 70 & 0.055 \\
\hline & Kontrol & 0.119 & 70 & $0.200^{*}$ \\
\hline
\end{tabular}

a. Lilliefors Significance Correction 
Berdasarkan Tabel 6 menunjukkan bahwa hasil Tests of Normality Kolmogorof-Smirnov dengan Lilliefors Significance Correction pada skor hasil belajar kognitif kelas eksperimen terdistribusi normal dengan angka signifikansi 0,055 >0,05 dan skor hasil belajar kognitif kelas kontrol terdistribusi normal dengan angka signifikansi 0,200 > 0,05. Dari hasil analisis ini dapat dikatakan bahwa sebaran skor hasil belajar kognitif pada setiap kelas eksperimen dan kelas kontrol berdistribusi normal sehingga uji normalitas sebagai uji prasyarat terpenuhi.

Tabel 7. Hasil Uji Normalitas Skor Hasil Belajar Kognitif Bermotivasi belajar Rendah dan Tinggi

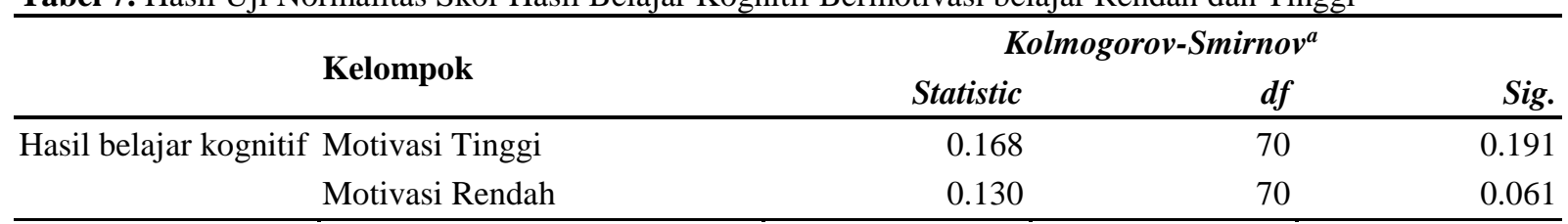

\section{a. Lilliefors Significance Correction}

Berdasarkan Tabel 7 menunjukkan bahwa hasil Tests of Normality Kolmogorof-Smirnov dengan Lilliefors Significance Correction pada skor hasil belajar kognitif bermotivasi belajar tinggi terdistribusi normal dengan angka signifikansi $0,191>0,05$ dan skor hasil belajar kognitif berpengetahuan rendah terdistribusi normal dengan angka signifikansi 0,061 > 0,05. Dari hasil analisis ini dapat dikatakan bahwa sebaran skor hasil belajar kognitif pada siswa bermotivasi belajar tinggi dan rendah berdistribusi normal sehingga uji normalitas sebagai uji prasyarat terpenuhi.

Tabel 8 . Hasil Uji Normalitas Skor Hasil Pengamatan Penilaian Psikomotorik Kelas Eksperimen dan Kontrol

\begin{tabular}{llcrr}
\hline & & \multicolumn{2}{c}{ Kolmogorov-Smirnov $^{\boldsymbol{a}}$} \\
& Kelas & Statistic & Df & Sig. \\
\hline Hasil belajar kognitif & $\mathrm{E}(\mathrm{pbl})$ & 0.220 & 70 & 0.123 \\
& $\mathrm{~K}(\mathrm{dl})$ & 0.156 & 70 & 0.241 \\
\hline
\end{tabular}

Berdasarkan Tabel 8 menunjukkan bahwa hasil Tests of Normality Kolmogorof-Smirnov dengan Lilliefors Significance Correction pada skor hasil pengamatan penilaian psikomotorik kelas eksperimen terdistribusi normal dengan angka signifikansi 0,123>0,05 dan skor hasil pengamatan penilaian psikomotorik kelas kontrol terdistribusi normal dengan angka signifikansi 0,241 >0,05. Dari hasil analisis ini dapat dikatakan bahwa sebaran skor hasil pengamatan penilaian psikomotorik pada setiap kelas eksperimen dan kelas kontrol berdistribusi normal sehingga uji normalitas sebagai uji prasyarat terpenuhi.

Tabel 9. Hasil Uji Normalitas Skor Hasil Pengamatan Penilaian Psikomotorik Rendah dan Tinggi

\begin{tabular}{|c|c|c|c|c|}
\hline & \multirow{2}{*}{ Kelompok } & \multicolumn{2}{|c|}{ Kolmogorov-Smirnov ${ }^{a}$} & \multirow[b]{2}{*}{ Sig. } \\
\hline & & Statistic & $d f$ & \\
\hline \multirow[t]{2}{*}{ Hasil belajar kognitif } & Motivasi Tinggi & 0.898 & 70 & 0.199 \\
\hline & Motivasi Rendah & 0.928 & 70 & 0.181 \\
\hline
\end{tabular}

a. Lilliefors Significance Correction

Berdasarkan Tabel 9 menunjukkan bahwa hasil Tests of Normality Kolmogorof-Smirnov dengan Lilliefors Significance Correction pada skor hasil pengamatan penilaian psikomotorik bermotivasi belajar tinggi terdistribusi normal dengan angka signifikansi 0,199>0,05 dan skor hasil pengamatan penilaian psikomotorik berpengetahuan rendah terdistribusi normal dengan angka signifikansi 0,181 $>0,05$. Dari hasil analisis ini dapat dikatakan bahwa sebaran skor hasil pengamatan penilaian psikomotorik pada siswa bermotivasi belajar tinggi dan rendah berdistribusi normal sehingga uji normalitas sebagai uji prasyarat terpenuhi.

Tabel 10. Hasil Uji Normalitas Skor Hasil Pengamatan Penilaian Afektif Kelas Eksperimen dan Kontrol

\begin{tabular}{llcrr}
\hline & & \multicolumn{2}{c}{ Kolmogorov-Smirnov $^{\boldsymbol{a}}$} \\
& Kelas & Statistic & Df & Sig. \\
\hline Hasil belajar kognitif & $\mathrm{E}(\mathrm{pbl})$ & 0.892 & 70 & 0.160 \\
& $\mathrm{~K}(\mathrm{dl})$ & 0.915 & 70 & 0.153 \\
\hline
\end{tabular}

a. Lilliefors Significance Correction 
Berdasarkan Tabel 10 menunjukkan bahwa hasil Tests of Normality Kolmogorof-Smirnov dengan Lilliefors Significance Correction pada skor hasil pengamatan penilaian afektif kelas eksperimen terdistribusi normal dengan angka signifikansi $0,160>0,05$ dan skor hasil pengamatan penilaian afektif kelas kontrol terdistribusi normal dengan angka signifikansi 0,153>0,05. Dari hasil analisis ini dapat dikatakan bahwa sebaran skor hasil pengamatan penilaian afektif pada setiap kelas eksperimen dan kelas kontrol berdistribusi normal sehingga uji normalitas sebagai uji prasyarat terpenuhi.

Berdasarkan Tabel 11 menunjukkan bahwa hasil Tests of Normality Kolmogorof-Smirnov dengan Lilliefors Significance Correction pada skor hasil pengamatan penilaian afektif bermotivasi belajar tinggi terdistribusi normal dengan angka signifikansi 0,151>0,05 dan skor hasil pengamatan penilaian afektif bermotivasi rendah terdistribusi normal dengan angka signifikansi 0,105 > 0,05. Dari hasil analisis ini dapat dikatakan bahwa sebaran skor hasil pengamatan penilaian afektif pada siswa bermotivasi belajar tinggi dan rendah berdistribusi normal sehingga uji normalitas sebagai uji prasyarat terpenuhi.

Tabel 11. Hasil Uji Normalitas Skor Hasil Pengamatan Penilaian Afektif Rendah dan Tinggi

\begin{tabular}{|c|c|c|c|c|}
\hline & \multirow{2}{*}{ Kelompok } & \multicolumn{2}{|c|}{ Kolmogorov-Smirnov } & \multirow[b]{2}{*}{ Sig. } \\
\hline & & Statistic & $d f$ & \\
\hline \multirow[t]{2}{*}{ Hasil belajar kognitif } & Motivasi Tinggi & 0.938 & 70 & 0.151 \\
\hline & Motivasi Rendah & 0.955 & 70 & 0.105 \\
\hline
\end{tabular}

\section{c. Uji Homogenitas}

Uji homogenitas dilakukan untuk mengetahui apakah dua kelompok data yang diteliti memiliki varian yang homogen atau tidak. Homogenitas varian diuji dengan menggunakan Levene's Test of Equaty or Error Variances. Ringkasan homogenitas varian dapat dilihat pada Tabel 12.

Tabel 12. Hasil Uji Homogenitas Skor Hasil Belajar Kognitif Kelas Eksperimen-Kontrol

\begin{tabular}{llrrrr}
\hline & \multicolumn{2}{c}{ Test of Homogeneity of Variance } & & \\
\hline & Levene Statistic & $\boldsymbol{d f 1}$ & $\boldsymbol{d f 2}$ & Sig. \\
\hline Hasil belajar & Based on Mean & 0.103 & 1 & 138 & 0.749 \\
kognitif & Based on Median & 0.068 & 1 & 138 & 0.794 \\
& Based on Median and with adjusted & 0.068 & 1 & 135.189 & 0.794 \\
& df & & & 138 & 0.717 \\
\hline
\end{tabular}

Berdasarkan Tabel 12 hasil Levene's Test of Equaty or Error Variances menunjukkan bahwa data skor hasil belajar kognitif untuk kelas eksperimen-kontrol adalah homogen dengan angka signifikansi Base on Mean sebesar 0,749 > 0,05 Dari hasil analisis ini dapat dikatakan bahwa sebaran skor hasil belajar kognitif pada setiap kelas eksperimen-kontrol adalah homogen sehingga uji homogenitas sebagai uji prasyarat terpenuhi.

Tabel 13. Hasil Uji Homogenitas Skor Hasil Belajar Kognitif Bermotivasi Belajar Tinggi-Rendah

\section{Test of Homogeneity of Variance}

\begin{tabular}{llrrrr} 
& & Levene Statistic & df1 & df2 & Sig. \\
\hline Hasil belajar & Based on Mean & 0.020 & 1 & 138 & 0.889 \\
kognitif & Based on Median & 0.001 & 1 & 138 & 0.975 \\
& Based on Median and with adjusted & 0.001 & 1 & 132.455 & 0.975 \\
& $d f$ & & & \\
& Based on trimmed mean & 0.026 & 1 & 138 & 0.872 \\
\hline
\end{tabular}

Berdasarkan Tabel 13 hasil Levene's Test of Equaty or Error Variances menunjukkan bahwa data skor hasil belajar kognitif untuk siswa bermotivasi belajar rendah-tinggi adalah homogen dengan angka signifikansi Base on Mean sebesar 0,472 > 0,05. Dari hasil analisis ini dapat dikatakan bahwa sebaran skor hasil belajar kognitif pada siswa bermotivasi belajar tinggi-rendah adalah homogen sehingga uji homogenitas sebagai uji prasyarat terpenuhi. 
Tabel 14. Hasil Uji Homogenitas Skor Hasil Pengamatan Penilaian Psikomotorik Kelas Eksperimen-Kontrol

\begin{tabular}{llrrrr}
\hline \multicolumn{4}{c}{ Test of Homogeneity of Variance } & & \\
& Levene Statistic & df 1 & df 2 & Sig. \\
\hline Hasil belajar & Based on Mean & 0.015 & 1 & 138 & 0.903 \\
kognitif & 0.140 & 1 & 138 & 0.709 \\
& Based on Median & 0.140 & 1 & 136.347 & 0.709 \\
& Based on Median and with adjusted & & & & \\
& df & 0.051 & 1 & 138 & 0.822 \\
\hline
\end{tabular}

Berdasarkan Tabel 14 hasil Levene's Test of Equaty or Error Variances menunjukkan bahwa data skor hasil belajar kognitif untuk kelas eksperimen-kontrol adalah homogen dengan angka signifikansi Base on Mean sebesar 0,903 > 0,05 Dari hasil analisis ini dapat dikatakan bahwa sebaran skor hasil belajar kognitif pada setiap kelas eksperimen-kontrol adalah homogen sehingga uji homogenitas sebagai uji prasyarat terpenuhi.

Tabel 15. Hasil Uji Homogenitas Skor Hasil Pengamatan Penilaian Psikomotorik Bermotivasi Belajar Tinggi Rendah

\begin{tabular}{llrrrr}
\hline & \multicolumn{2}{c}{ Test of Homogeneity of Variance } & & \\
& & Levene Statistic & df1 & df2 & Sig. \\
\hline Hasil belajar & Based on Mean & 0.496 & 1 & 138 & 0.483 \\
kognitif & Based on Median & 0.287 & 1 & 138 & 0.593 \\
& Based on Median and with adjusted & 0.287 & 1 & 130.404 & 0.593 \\
& df & & & \\
& Based on trimmed mean & 0.289 & 1 & 138 & 0.592 \\
\hline
\end{tabular}

Berdasarkan Tabel 15 hasil Levene's Test of Equaty or Error Variances menunjukkan bahwa data skor hasil pengamatan penilaian psikomotorik untuk siswa bermotivasi belajar rendah-tinggi adalah homogen dengan angka signifikansi Base on Mean sebesar 0,483 > 0,05. Dari hasil analisis ini dapat dikatakan bahwa sebaran skor hasil pengamatan penilaian psikomotorik pada siswa bermotivasi belajar tinggi-rendah adalah homogen sehingga uji homogenitas sebagai uji prasyarat terpenuhi.

Tabel 16. Hasil Uji Homogenitas Skor Hasil Pengamatan Penilaian Afektif Kelas Eksperimen-Kontrol

\begin{tabular}{|c|c|c|c|c|c|}
\hline \multicolumn{6}{|c|}{ Test of Homogeneity of Variance } \\
\hline & & Levene Statistic & $d f 1$ & $d f 2$ & Sig. \\
\hline \multirow{4}{*}{$\begin{array}{l}\text { Hasil belajar } \\
\text { kognitif }\end{array}$} & Based on Mean & 10.439 & 1 & 138 & 0.152 \\
\hline & Based on Median & 9.712 & 1 & 138 & 0.162 \\
\hline & $\begin{array}{l}\text { Based on Median and with adjusted } \\
d f\end{array}$ & 9.712 & 1 & 137.474 & 0.242 \\
\hline & Based on trimmed mean & 10.479 & 1 & 138 & 0.252 \\
\hline
\end{tabular}

Berdasarkan Tabel 16 hasil Levene's Test of Equaty or Error Variances menunjukkan bahwa data skor hasil pengamatan penilaian afektif untuk kelas eksperimen-kontrol adalah homogen dengan angka signifikansi Base on Mean sebesar 0,152 > 0,05 Dari hasil analisis ini dapat dikatakan bahwa sebaran skor hasil pengamatan penilaian afektif pada setiap kelas eksperimen-kontrol adalah homogen sehingga uji homogenitas sebagai uji prasyarat terpenuhi.

Tabel 17. Hasil Uji Homogenitas Skor Hasil Pengamatan Penilaian Afektif Bermotivasi Belajar Tinggi-Rendah

\section{Test of Homogeneity of Variance}

\begin{tabular}{llrrrr} 
& & Levene Statistic & df1 & df2 & Sig. \\
\hline Hasil belajar & Based on Mean & 5.469 & 1 & 138 & 0.221 \\
kognitif & Based on Median & 5.092 & 1 & 138 & 0.226 \\
& Based on Median and with adjusted & 5.092 & 1 & 129.107 & 0.226 \\
& $d f$ & & & & \\
& Based on trimmed mean & 5.533 & 1 & 138 & 0.220 \\
\hline
\end{tabular}


Berdasarkan Tabel 17 hasil Levene's Test of Equaty or Error Variances menunjukkan bahwa data skor hasil pengamatan penilaian afektif untuk siswa bermotivasi belajar rendah-tinggi adalah homogen dengan angka signifikansi Base on Mean sebesar 0,221 > 0,05. Dari hasil analisis ini dapat dikatakan bahwa sebaran skor hasil belajar kognitif pada siswa bermotivasi belajar tinggi-rendah adalah homogen sehingga uji homogenitas sebagai uji prasyarat terpenuhi.

$\mathrm{H}_{0}$ : Tidak terdapat pengaruh interaksi antara model pembelajaran PBL dan model direct learning dengan motivasi belajar siswa terhadap hasil belajar Fisika pada siswa Kelas XI IPA SMA Negeri 1 Dawarblandong dan SMA Negeri 2 Kota Mojokerto.

$\mathrm{H}_{1} \quad$ : Terdapat pengaruh interaksi antara model pembelajaran PBL dan model direct learning dengan motivasi belajar siswa terhadap hasil belajar Fisika pada siswa Kelas XI IPA SMA Negeri 1 Dawarblandong dan SMA Negeri 2 Kota Mojokerto.

Hasil uji Anava Dua Jalur diperoleh nilai $\mathrm{F}_{\text {hitung }}=9,985$ dengan angka signifikansi sebesar 0,003 lebih besar dari 0,05, Tabel 4.23 diperoleh nilai $F_{\text {hitung }}=$ 5,390 dengan angka signifikansi sebesar 0,004 lebih besar dari 0,05 , Tabel 4.24 diperoleh nilai $F_{\text {hitung }}=15,663$ dengan angka signifikansi sebesar 0,000 lebih besar dari 0,05 . Hasil ini dapat diinterpretasikan bahwa hipotesis nol nol $\left(\mathrm{H}_{0}\right)$ ditolak dan hipotesis satu $\left(\mathrm{H}_{1}\right)$ diterima artinya terdapat pengaruh interaksi antara model pembelajaran PBL dan model direct learning dengan motivasi belajar siswa terhadap hasil belajar Fisika.

Adanya interaksi antara penggunaan pembelajaran model pembelajaran PBL dan model pembelajaran direct learning serta motivasi belajar siswa terhadap hasil belajar dikarenakan model pembelajaran dipilih secara tepat dan dipergunakan sebagai strategi dalam pembelajaran, serta motivasi siswa yang merupakan motif yang mendorong seseorang berpacu dengan keunggulan orang lain dan keunggulan diri sendiri sehngga kecenderungan seseorang untuk meningkatkan atau mempertahankan kecakapan dalam semua bidang dengan standar kualitas sebagai pedomannya, yang pada akhimya hasil belajar siswa dapat diketahui setelah perlakuan pembelajaran dengan instrumen tes hasil belajar Fisika.

Motivasi siswa sangat erat kaitannya dengan kemampuan, sehingga orang mengatakan ada kemampuan yang terkandung di dalam pribadi orang yang penuh motivasi. Motivasi siswa merupakan kecenderungan seseorang untuk mereaksi terhadap situasi untuk mencapai suatu hasil yang ditampilkan dalam bentuk tingkah laku. Motivasi siswa merupakan motif yang mendorong seseorang berpacu dengan keunggulan orang lain dan keunggulan diri sendiri.

Pada hakikatnya motivasi belajar merupakan dorongan terjadinya belajar. Terutama motivasi yang timbul dari diri peserta didik, apabila motivasi belajar tinggi maka siswa pun akan dengan baik mengikuti setiap proses pembelajaran yang berlangsung. Dimyati \& Mudjiono (2013) menyebutkan motivasi belajar merupakan kekuatan mental yang mendorong terjadinya belajar. Motivasi dalam proses belajar sangat diperlukan peserta didik untuk menunjang mereka dalam bertindak guna mencapai tujuan belajar yang hendak mereka capai.

\section{Simpulan}

Berdasarkan hasil penelitian dan diskusi penelitian maka dapat ditarik kesimpulan bahwa:terdapat pengaruh interaksi antara model pembelajaran pembelajaran PBL dan model pembelajaran direct learning dengan motivasi belajar siswa terhadap hasil belajar Fisika siswa Kelas XI IPA SMAN 1 Dawarblandong dan SMAN 2 Kota Mojokerto. Berdasarkan penelitian yang telah dilakukan, peneliti mengajukan beberapa saran untuk pihak-pihak terkait dengan penelitian ini sebagai referensi yang disiminasikan kepada rekan-rekan peneliti lainnya, untuk lebih aktif melakukan penelitian khusus di bidang model pembelajaran PBL dan model direct learning maupun yang lainnya.

\section{Daftar Pustaka}

Aqib, Z., \& Murtadlo, A. (2016). Kumpulan Metode Pembelajaran Kreatif dan Inovatif. Bandung: Sarana Tutorial Nurani Sejahtera.

Ernawati. (2017). Pengaruh Pembelajaran Berbasis Masalah terhadap Hasil Belajar IPA Ditinjau dari Kemampuan Berpikir Kritis. Jurnal Ilmiah Pendidikan IPA, 4 (1) 49-54

Harahap, N. (2014). Hubungan antara Motivasi dan Aktivitas Belajar Siswa terhadap Hasil Belajar Kognitif Siswa dengan Penerapan Model Pembelajaraan Kooperatif Tipe Student Teams Achievement Division pada Konsep Ekosistem. STKIP Bina Bangsa Getsempena Banda Aceh, V(1) 35-46.

Ma'mur, A. (2016). Tips Efektif Cooperative Learning. Yogyakarta: Diva Press.

Ngalimun. (2017). Strategi Pembelajaran Dilengkapi dengan 65 Model Pembelajaran. Yogyakata: Parama Ilmu.

Nur, M. (2011). Model Pengajaran Langsung, Dilengkapi Contoh Perangkat RPP Keterampilan Berpikir dan Pendidikan Karakter Edisi Kedua. Surabaya: Unipress.

Pitriah, S. \& Taufik, M. (2018). Pengaruh Model Pembelajaran Berbasis Masalah Berbantuan Alat Peraga Tiga Dimensi terhadap Hasil Belajar Fisika Peserta Didik Tahun Pelajaran 2017/2018. Jurnal Pendidikan Fisika dan Teknologi, 4 (2) 283-290. 
Renata, H., \& Sihombing, E. (2016). Pengaruh Model Pembelajaran Berbasis Masalah terhadap Hasil Belajar pada Materi Listrik Dinamis. Jurnal Ikatan Alumni Fisika Universitas Negeri Medan, 2 (2) 44-49.

Rusman. (2012). Seri Managemen Sekolah Bermutu, Model-Model Pembelajaran Mengembangkan Profesionalisme Guru. Depok: Raja Grafindo Persada.

Rusman. (2014). Seri Managemen Sekolah Bermutu, Model-Model Pembelajaran Mengembangkan Profesionalisme Guru. Depok: Raja Grafindo Persada. 